\title{
INFLUENCE OF KUNG FU TRAINING ON SCIENTIFIC PERSONALITY
}

\author{
Albena Dimitrova \\ National Sports Academy "Vassil Levski", Sofia, Bulgaria
}

\begin{abstract}
The rapid changes that occur independently of us in the environment in which we live make us constantly face new situations and new adaptation requirements. Continuous race with time for modern pupil naturally raises its anxiety, which is a complex emotional negative experience that reflects on the structure of mental readiness. This ability can be acquired through systematic, physical training during the kung fu training process.

The aim of the research is to reveal the impact of kung fu training on the anxiety of 5th and 8th grade students, peculiarities of manifestation and subsequent adequate socialization through sport.

The subject of the present study is a total of 140 students from Sofia, which are divided into two experimental and two control groups.

In order to solve the main tasks, the achievement of the goal and prove the hypothesis is applied a complex methodology from literary sources study, observation, talk, content analysis and questionnaire for situational and personal anxiety. On the basis of the analyzed results and the knowledge of the revealed regularities, the hypothesis is shown that in systemic kung fu training, the anxiety is reduced. There are valuable personal traits and psychic qualities that are shown in practice as effective actions and adequate behavior in different extreme situations.
\end{abstract}

Key words: kung $f u$, anxiety, students, socialization.

\section{INTRODUCTION}

Changes cover the overall functioning and development of society, affect the socialization and behavior of people, and test the ability to adapt to both society and its institutions and institutions, as well as social groups and individuals (Serafimova, 2006).

This continuous race with time for the modern man naturally increases his anxiety. It presents us with many alternatives, among which we must decide to deal with dynamic conditions. In recent years, anxiety has become one of the major mental health problems worldwide. It is an inevitable companion in the life of modern society. In many everyday situations and challenges, it is logical and appropriate to respond with some anxiety (Rogleva, 2009).

There is a complex of causes for anxiety at different levels of sport, reflecting on students and sports as a major social institute. It is a mental state in a person in which protective reactions are triggered without any direct incitement. It is most often the result of a lack of control and security over the present and the future. It is also an emotion that signals a possible, expected, undifferentiated, unclear threat (Desev, 2005; Burkurt, Dishman, 2002; Brammer, 1996). The human ability to foresee a possible future and think of all possible alternatives is the basis for the emergence of anxiety (Dimitrov, 2010).

They can be supplemented and combined with the main components in the course of crises from a sociological point of view, namely: 'sources of crisis (problems, contradictions); symptoms (and is, the peculiarities of the subjective reflection of the contradictions that manifest themselves in the behavior of the athletes); possible circumstances complicating the course of the crisis; ways out of the crisis; the impact of the crisis on the successful performance of the athlete; forms of 'payment' for absence of crisis and peculiarities of psychological support for athletes' (Lubisheva, 2004).

Crisis descriptions, as well as descriptions taking into account the particularities of sports activities, are the basis for predicting possible negative situations. Forecasting helps students, coaches and anyone interested in this issue to avoid the mistakes that are occurring in the life course of young athletes.

Measurement of anxiety as a trait of personality is particularly important, since it is to a large extent that determines the student's behavior and is an essential component of self-control and self-educa- 
tion (Ivanov, 1999). In each particular social actor, personal and situational anxiety is developed to varying degrees.

Anxiety determines the individual's sensitivity to competitive stress. The personality trait is characterized by the degree of aptitude for fear. Anxiety is most often associated with anticipating the social consequences of success or failure (Shtetinski, Paspalanov, 1989; Buckworth, \& Dishman, 2002).

One of the main factors that influence the structure of mental readiness is personal and situational anxiety. With increasing anxiety, cognitive processes are reduced, which results in a decrease in mental fitness. Anxiety as a complex emotional negative experience strongly affects the structuring of mental readiness (Kaykov, 1997; Margaritov, 1999).

The social problems listed are a consequence of the contradiction between the needs and the means to satisfy them, which in public life manifests itself as a contradiction between the actual and the desired state. Therefore, social problematization is not a phase of awareness and definition of the problem situation, but a phase of elaboration, planning of the problem solution and its solution through organized activity (Dimitrov, 1997).

The discussed issues are directly or indirectly related and related to the system of scientific knowledge and classification of the necessary knowledge, skills and habits in the field of school physical education, sociology of sport, sports psychology, sports pedagogy, sports training and more (Tsonev, 1996, 1997, 2001; Iancheva, Dimitrova, 1996; Iancheva, 2004, 2006, 2017; Georgiev, 1996; Mileva, 2001, 2012; Penov, 2012).

\section{METHODOLOGY}

On the basis of theoretical analysis, the following hypothesis is made: systematic kung fu training will significantly reduce anxiety and form valuable personality traits and psychic qualities that are manifested in practice as effective actions and adequate

\begin{tabular}{|c|c|c|c|c|}
\hline \multirow{2}{*}{$\begin{array}{c}\text { Investigated } \\
\text { group } \\
\text { indicators }\end{array}$} & \multicolumn{2}{|c|}{$\begin{array}{c}\text { Situational } \\
\text { anxiety }\end{array}$} & \multicolumn{2}{c|}{$\begin{array}{c}\text { Personal } \\
\text { anxiety }\end{array}$} \\
\cline { 2 - 5 } & $\mathbf{X}_{\text {cp.1 }}$ & $\mathbf{S}_{1}$ & $\mathbf{X}_{\text {cp.2 }}$ & $\mathbf{S}_{2}$ \\
\hline Control & 41.62 & 7.87 & 41.38 & 7.73 \\
\hline Experimental & 33.21 & 8.75 & 35.94 & 7.85 \\
\hline $\mathbf{d}$ & 8.41 & - & 5.38 & - \\
\hline $\mathbf{P}$ & 99 & - & - & 98 \\
\hline
\end{tabular}

Table 1. Anxiety of fifth grade students behavior in various extreme situations.

The purpose of the research is to find out the impact of Kung Fu training on the anxiety of 5th and 8th grade students, peculiarities of manifestation and subsequent adequate socialization through sport.

The aim of the present publication is to enhance the theoretical and practical knowledge of real and potential users (specialists, students, people with respect to sport).

For realization of the research the following objectives are outlined:

$\checkmark$ to study literary sources related to the problem;

$\checkmark$ to outline and analyze the impact of practicing kung fu on the anxiety of students in grades 5 and 8;

$\checkmark$ to identify and analyze the leading relationship between students' anxiety and the role of kung $\mathrm{fu}$ for their adequate socialization through sports and improving their quality of life.

The object of this study is a total of 140 students from two schools in Sofia (55 kung fu trainers and 85 non-practitioners), which are divided into two experimental groups (systematic kung fu practitioners) and two control groups (non-practitioners) certain sport).

Complex methodology of literature research, observation, conversation, content analysis and situational and personality anxiety questionnaire was applied to solve the main tasks, achieve the goal and prove the hypothesis.

Organization of the conducted tests: 20.09.2018 28.06.2019.

\section{RESULTS}

While analyzing the results of the study, regularities of theory and practice were revealed. It was found that the situational anxiety of the students in the 5th grade of the control group not practicing a certain type of sport is 41.62 points at $S=7.87$. The level of anxiety of the respondents is normal.

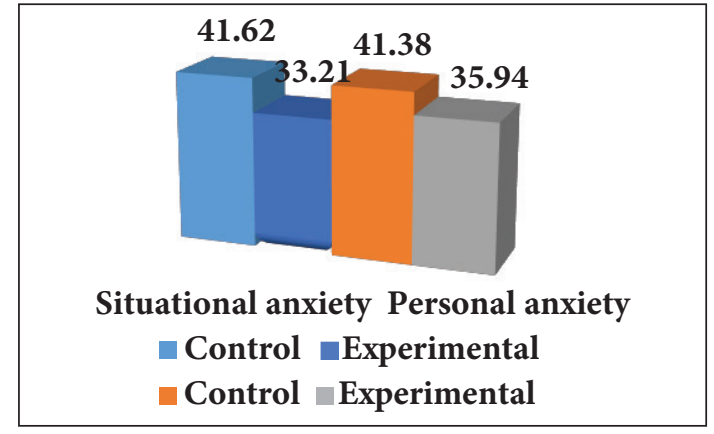

Figure 1. Anxiety of fifth grade students 
Some students show signs of higher anxiety. They are more tense and uncertain. The students in the experimental group systematically practicing kung fu situational anxiety was 33.21 points at $S=8.75$, and is it was 8.41 points lower than the students in the control group $(\mathrm{P}=99 \%)$. This large significant difference in levels of situational anxiety is evidence that it is the practice of kung fu that has a positive effect on the reduction of situational anxiety. The students in the experimental group are calmer and more determined. They more easily overcome various difficulties than students in the control group who do not practice a particular sport.

Practicing kung fu also had a positive effect on reducing the anxiety of students in the experimental group. As indicated in Table 1 with 5.44 points, they had lower personal anxiety compared to the students in the control group ( $\mathrm{P}=99 \%)$. Systematic training positively influenced the change of per-

\begin{tabular}{|c|c|c|c|c|}
\hline $\begin{array}{c}\text { Investigated } \\
\text { group } \\
\text { indicators }\end{array}$ & \multicolumn{2}{|c|}{$\begin{array}{c}\text { Situational } \\
\text { anxiety }\end{array}$} & \multicolumn{2}{c|}{$\begin{array}{c}\text { Personal } \\
\text { anxiety }\end{array}$} \\
\cline { 2 - 5 } & $\mathbf{X}_{\mathrm{cp} .2}$ & $\mathbf{S}_{\mathbf{1}}$ & $\mathbf{X}_{\mathrm{cp} . \mathbf{2}}$ & $\mathbf{S}_{\mathbf{2}}$ \\
\hline Control & 40.47 & 8.92 & 43.15 & 7.93 \\
\hline Experimental & 33.90 & 6.61 & 36.12 & 6.84 \\
\hline $\mathbf{d}$ & 6.57 & - & 7.03 & - \\
\hline $\mathbf{P}$ & 99 & - & - & 98 \\
\hline
\end{tabular}

Table 2. Anxiety of fifth grade students

In the experimental group of Kung Fu practitioners, situational anxiety was 33.90 points at $S=6.61$, and is 6.57 points lower than the control group students $(\mathrm{P}=99 \%)$. The students in the experimental group, as a result of systemic kung fu training, have developed a greater psychic willingness to respond to a variety of extreme situations. The relatively low situational anxiety in them is a sign of a higher situational readiness for effective action in overcoming various difficulties.

Kung Fu training had a greater impact on the per-

\begin{tabular}{|c|c|c|c|c|}
\hline \multirow{2}{*}{$\begin{array}{c}\text { Investigated } \\
\text { group } \\
\text { indicators }\end{array}$} & \multicolumn{2}{|c|}{$\begin{array}{c}\text { Situational } \\
\text { anxiety }\end{array}$} & \multicolumn{2}{c|}{$\begin{array}{c}\text { Personal } \\
\text { anxiety }\end{array}$} \\
\cline { 2 - 5 } & $\mathbf{X}_{\text {cp. } 1}$ & $\mathbf{S}_{1}$ & $\mathbf{X}_{\text {cp. } 2}$ & $\mathbf{S}_{\mathbf{2}}$ \\
\hline Control & 40.42 & 7.15 & 41.12 & 6.76 \\
\hline Experimental & 35.87 & 7.55 & 30.05 & 6.27 \\
\hline $\mathbf{d}$ & 4.55 & - & 11.07 & - \\
\hline $\mathbf{P}$ & $99 \%$ & - & - & $99 \%$ \\
\hline
\end{tabular}

Table 3. Eighth grade students' anxiety sonality of the students in the experimental group. They are calmer and more confident than the students in the control group. According to the results obtained, kung fu training positively influenced the development of the students' personality in the experimental group.

The study found that kung fu training had a strong effect on reducing anxiety. There is also a decrease in nervous mental tension, as a result of which the mental powers are restored, and personal anxiety is reduced. Strong influence is logical, as training in kung fu affects the emotional sphere of the students and transforms the negative emotional experiences into positive ones.

The changes in anxiety in the girls in the 5th grade experimental group are similar. The situational anxiety of the control group students was 40.47 points at $S=8.92$ (Table 2).

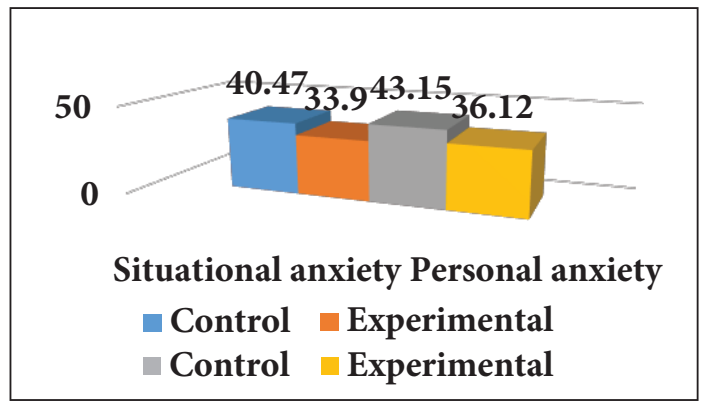

Figure 2. Anxiety of fifth grade students

sonal anxiety of the students in the experimental group. As can be seen from Table. 2, with 7.03 points, their personal anxiety was lower than the students in the control group ( $\mathrm{P}=99 \%)$. In the experimental group, as a result of practicing kung fu, their personality was refined and the subjects studied established strong positive traits for effective action under various difficult conditions.

Grade 8 students have significantly lower situational and personality anxiety than non-sporting students (Table 3 and Table 4).

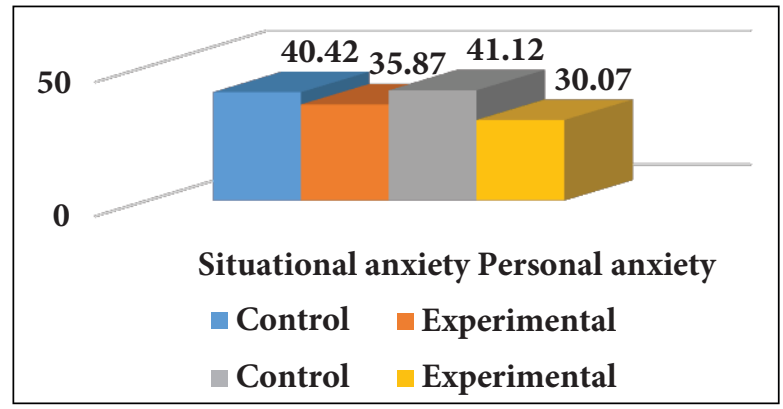

Figure 3. Anxiety of eighth grade students 
As can be seen from Table. 3 students in the experimental group had 4.55 points lower situational anxiety than the students in the control group ( $\mathrm{P}$ $=99 \%)$. The continued practice of kung fu has had an impact on forming students' situational mental preparedness to cope with stress and achieve their goals. Systematic training in kung fu has permanently influenced the formation of stable personality traits of students and students in the experimental group, such as perseverance, determination, discipline. Personal anxiety was lower by 11.07 compared to the control group ( $\mathrm{P}=99 \%)$.

\begin{tabular}{|c|c|c|c|c|}
\hline \multirow{2}{*}{$\begin{array}{c}\text { Investigated } \\
\text { group } \\
\text { indicators }\end{array}$} & \multicolumn{2}{|c|}{$\begin{array}{c}\text { Situational } \\
\text { anxiety }\end{array}$} & \multicolumn{2}{c|}{$\begin{array}{c}\text { Personal } \\
\text { anxiety }\end{array}$} \\
\cline { 2 - 5 } & $\mathrm{X}_{\mathrm{cp} .1}$ & $\mathrm{~S}_{1}$ & $\mathrm{X}_{\mathrm{cp} .2}$ & $\mathrm{~S}_{2}$ \\
\hline Control & 40.71 & 8.3 & 44.12 & 8.5 \\
\hline Experimental & 35.87 & 8.1 & 33.85 & 7.2 \\
\hline $\mathbf{d}$ & 4.84 & - & 10.27 & - \\
\hline $\mathbf{P}$ & 97 & - & - & 99 \\
\hline
\end{tabular}

Table 4. Anxiety of 8-th grade students

Female students in the experimental group had a lower score of 4.84 in situational anxiety compared to female students in the control group ( $\mathrm{P}$ $=97 \%)$. In the process of training and competitions, skills have been steadily formed in the students to limit their situational anxiety and show determination in extreme situations. Active physical activities in Kung Fu practices have, to one degree or another, positively influenced the formation of these skills.

Systematic training and competitions have had a positive effect on personal anxiety. Sustainable changes have taken place. Positive personality traits of students practicing kung fu have been formed. By 10.27 points, the personal anxiety score of the experimental group students was lower than that of the control group ( $\mathrm{P}=99 \%)$. This high difference in personality anxiety is evidence of the positive impact of Kung Fu personality anxiety training and competitions in female students. The lowering of anxiety improves the psyche. Valuable psychic qualities are formed in the examined.

\section{CONCLUSION}

On the basis of the analysed results and summaries of the regularities revealed, it is proved that in systemic kung fu training, anxiety is significantly reduced. Valuable personality traits and psychic qualities are formed, which are manifested in prac-
With the reduction of personal anxiety, the observation is improved, the mental capacity is increased, the activity is increased. The negative impact of negative emotions on mental activity and will is limited. The psyche of the students in the control group is being improved.

Analysing the results of the study, it was found that systematic 8th grade kung fu students also had lower situational anxiety than non-sporting students.

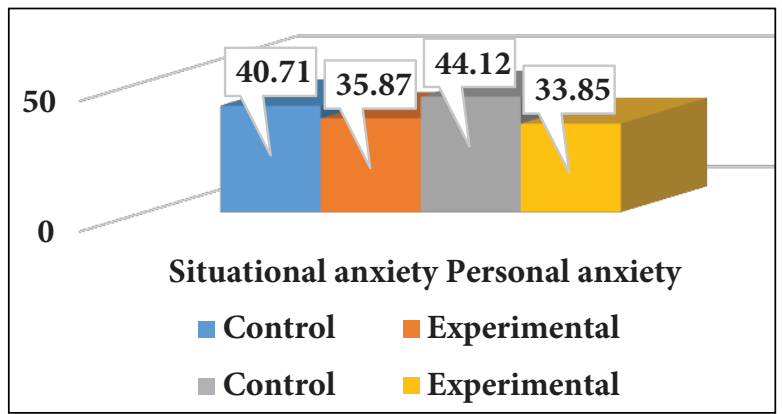

Figure 4. Anxiety of 8th grade students

tice as effective actions and adequate behavior in various extreme situations.

Kung Fu has a significant influence on the adequate socialization of athletes and the development of an adequate life strategy.

Knowledge and creative mastery of knowledge in this field of science and their application in practice changes in a positive direction the mental, physical development and capacity, and as a result the health status and academic achievement of students.

\section{REFERENCES}

Brammer, L. (1996). Obituary. American psychologist $51(1), 52$.

Buckworth, J., Dishman, R. (2002). Exercise Psychology, in Human Kinetics Champaign.

Desev, L. (2005). Rechnik po psihologia, Bulgarika, Sofia. // Десев, Л. (2005). Речник по психология, Булгарика, София.

Dimitrov, V. (2010). Osobenosti na situativnata i lichnostna trevozhnost pri sastezateli po boyni sportove pri prilagane na psihicheski vazdeystvia, v Lichnost, motivatsia, sport, tom 15, NSA PRES, Sofia, pp. 159 - 163. // Димитров, В. (2010). Особености на ситуативната и личностна тревожност при състезатели по бойни спортове при прилагане на психически въздействия, в Личност, мотивация, спорт, том 15, НСА ПРЕС, София, с. $159-163$.

Dimitrov, V. (2017). Planirane na choveshkite resursi v sportnata deynost, v Predizvikatelstva i perspektivi 
pred sportnata nauka, NSA PRES, Sofia, pp. 12 - 18. // Димитров, В. (2017). Планиране на човешките ресурси в спортната дейност, в Предизвикателства и перспективи пред спортната наука, с. 12 - 18, София, НСА ПРЕС.

Dimitrov, R. (1997). Problem, sotsialen, v Entsiklopedichen rechnik po sotsiologia, Vtoro izdanie, BAN, „M-8-M“', Sofia, pp. 353. // Димитров, Р. (1997). Проблем, социален, в Енциклопедичен речник по социология, Второ издание, БАН, „М-8-М “, София, с. 353. Georgiev, M. (1996). Psihologicheski trening za izgrazhdane na aktivna psihicheska protivostresova zashtita, $\mathrm{v}$ Lichnost, motivatsia, sport, tom 2, NSA PRES, Sofia, pp. 35. // Георгиев, М. (1996). Психологически тренинг за изграждане на активна психическа противостресова защита, в Личност, мотивация, спорт, том 2, НСА ПРЕС, София, с. 35.

Ivanov, I. (1999). Metodiki za izsledvane na funktsionalnite sastoyania, Axios, Shumen, pp. 9. // Иванов, И. (1999). Методики за изследване на функиионалните състояния, Аксиос, Шумен, с. 9.

Kaykov, D. (1997). Nauchni osnovi na psihofizicheskata podgotovka, Sofia. // Кайков, Д. (1997). Научни основи на психофизическата подготовка, София.

Lubisheva, L. (2004). Sotsiologia fizicheskoy kulyturi i sporta, Uchebno posobie, Moskva, ACADEMA, pp. 234 // Лубышева, Л. (2004). Социология физической культуры и спорта, Учебно пособие, Москва, ACADEMA, c. 234.

Margaritov, V. (1999). Psihofizicheska podgotovka na sportista, Sofia. // Маргаритов, В. (1999). Психофизическа подготовка на спортиста, София.

Mileva, E. (2001). Pedagogicheski izmerenia na sporta $\mathrm{v}$ usloviyata na komersializatsia, $\mathrm{v}$ Lichnost, motivatsia, sport, tom 6, NSA PRES, Sofia, pp. 103. // Милева, Е. (2001). Педагогически измерения на спорта в условията на комерсиализация, в Личност, мотиваџия, спорт, том 6, НСА ПРЕС, София, стр. 103.

Mileva, E. (2012). Evropeyski izmerenia na sportnopedagogicheskoto obrazovanie, Avangard prima, Sofia, ISBN: 978-619-160-069-4. // Милева, Е. (2012). Европейски измерения на спортнопедагогическото образование, Авангард прима, София, ISBN: 978619-160-069-4.

Penov, R. (2012). Test to determinate the level of special training, in VI International Scientific Congress „Sport, Stress, Adaptation “17 - 19 May 2012 Sofia.

Rogleva, G. (2009). Predsystezatelna trevozhnost i stres v sporta, Monografia, Sofia, s. 17. // Роглева, Г. (2009). Предсъстезателна тревожност и стрес в спорта, Монография София, с. 17.

Serafimova, M. (2006). Ima li moderno sveshteno? Neophyte Rilski, Blagoevgrad. // Серафимова, М. (2006). Има ли модерно свещено? Неофит Рилски, Благоевград.
Tisma, M. (2007). Effect of psychological preparation to the competition results in swimmers in XII European congress of sport psychology, Greece.

Tsonev, S. (1996). Sportno prostranstvo i sportologia, v Sport \& nauka, br. 18. Sofia, pp. 29 - 34. // Цонев, С. (1996). Спортно пространство и спортология, в Спорт \& наука, бр. 18. София, с. $29-34$.

Tsonev, S. (1997). Sportat kato sotsialna institutsia, v Godishna nauchna konferentsia na NSA, 23 may 1995 g., Parvi tom, II sektsia, Sofia, pp. 5 - 11. // Цонев, С. (1997). Спортьт като социална институция, в Годишна научна конференция на НСА, 23 май 1995 г., Първи том, II секция, София, с. 5 - 11.

Tsonev, S. (2001). Relatsiyata „sportist - trenyor” v sportnoto prostranstvo, Sport \& nauka, kn. 5. Sofia, pp. 20-24. // Цонев, С. (2001). Релацията „спортист - треньор" в спортното пространство, Спорт \& наука, кн. 5. София, с. 20 - 24).

Iancheva, T., Dimitrova, Sv. (1996). Lichnostnata aktivnost - osnova za formirane na efektivno sastezatelno povedenie, v Godishna nauchna konferentsia na NSA, Sofia. // Янчева, Т., Димитрова. Св. (1996). Личностната активност - основа за формиране на ефективно състезателно поведение, в Годишна научна конференция на НСА, София.

Iancheva, T. (2004). Lichnost i sastezatelna realizatsia, NSA PRES, Sofia, ISBN 954-718-118-1. // Янчева, T. (2004). Личност и състезателна реализация, НСА ПРЕС, София, ISBN 954-718-118-1.

Iancheva, T. (2006). Psihologichesko osiguryavane $v$ elitnia sport, NSA PRESS, Sofia, ISBN 954-718171-8, pp. 8. // Янчева, Т. (2006). Психологическо осигуряване в елитния спорт, НСА ПРЕС, София, ISBN 954-718-171-8, c. 8).

Iancheva, T. (2017). Sportat - alternativa na agresivnoto povedenie, v nauchno spisanie „Profesionalno obrazovanie“, knizhka 6, Azbuki, Sofia, pp. 621 - 630. // Янчева, Т. (2017). Спортьт - алтернатива на агресивното поведение, в научно списание „Професионално образование “, книжка 6, Азбуки, София, с. 621 - 630).

Shtetinski, D., Paspalanov, I. (1989). Metodichesko posobie za rabota s balgarskata forma na vaprosnika za otsenka na trevozhnostta na Ch. Spilbrgar, BAN, Sofia. // Щетински, Д., Паспаланов, И. (1989). Методическо пособие за работа с българската форма на въпросника за оценка на тревожността на Ч. Спилбргър, БАН, София.

Corresponding author: Albena Dimitrova, Ph. D.

Department of Psychology, pedagogy and sociology National Sports Academy „Vassil Levski “ Studentski Grad, 21 Acad. Stefan Mladenov Str. 1700, Sofia, Bulgaria E-mail: albena234@abv.bg 